\title{
Prevalence, genetic profile of virulence determinants and multidrug resistance of Escherichia coli isolates from foods of animal origin
}

\author{
Mohd Rashid, Sanjay Kumar Kotwal, M. A. Malik and Maninder Singh \\ Division of Veterinary Public Health and Epidemiology, \\ Faculty of Veterinary Sciences and Animal Husbandry, Sher-e-Kashmir University of Agricultural \\ Sciences and Technology, Jammu, Jammu and Kashmir, India-181102. \\ Corresponding author: Mohd Rashid, email: rashidvph03@yahoo.co.in, Tel.: +91-9469004793 Fax: +91-1923-250639 \\ Received: 13-06-2012, Accepted: 22-07-2012, Published online: 14-01-2013
}

How to cite this article: Rashid M, Kotwal SK, Malik MA and Singh M (2013) Prevalence, genetic profile of virulence determinants and multidrug resistance of Escherichia coli isolates from foods of animal origin, Vet. World 6(3): 139-142, doi: 10.5455/vetworld.2013.139-142

\begin{abstract}
Aim: The aim of this study was to assess the hygienic quality of foods of animal origin. Thus samples from foods of animal origin, viz. mutton, chicken meat, milk and milk products were processed.

Materials and Methods: Two hundred samples from foods of animal origin viz., mutton, chicken meat, milk and milk products were processed for isolation of Escherichia coli. The isolates were got serotyped and also subjected to detection of virulence genes viz., stxl, stx2, eaeA and $h l y A$ by PCR.The isolates were also tested against commonly used antibiotics.

Results: The prevalence of $E$. coli was $30 \%$ in mutton, $40 \%$ in chicken meat, $33.96 \%$ in milk and $14.89 \%$ in milk products samples. All the 60 isolates of $E$. coli were grouped into 24 serogroups with $\mathrm{O} 60$ and $\mathrm{O} 123$ dominant strains (8.33\%) followed by $\mathrm{O} 22(6.66 \%)$. The PCR detected 21(10.5\%) of samples possessing stxl, 14(7\%) stx2, 3(1.5\%) both $s t x 1$ and stx2, 16(8\%), eaeA and 4(2\%) EHEC-hlyA gene. However, the prevalence of Shiga toxin producing E. coli (STEC) was $20 \%$ in mutton, $30 \%$ in chicken meat, $16.98 \%$ in milk and $8.51 \%$ in milk products. Whereas the prevalence of enteropathogenic $E$. coli (EPEC) was $2 \%$, in mutton, $4 \%$ in chicken meat, $7.54 \%$ in milk and $2.12 \%$ in milk products samples. The 4 isolates O60, O101, O131 and one untypeable strain possessed the EHEC-hlyA gene. 22 of 50 (44\%) of isolates from meat, milk and milk products showed multidrug resistance to four or more antimicrobial comprising ten of $25(40 \%)$ isolates from chicken meat samples and 12 of $25(48 \%)$ from milk and milk products were multidrug resistance to four or more antimicrobial.
\end{abstract}

Conclusions: It is concluded that partial cooked or raw milk, meat and their products prepared under unhygienic conditions may not be directly consumed as they may be carrying the pathogenic microbes.

Keywords: drug resistance, food, prevalence, serogroup

\section{Introduction}

Among emerging foodborne bacterial pathogens, Shiga toxin producing Escherichia coli (STEC) is a pathogen of concern associated with the change in the livestock practices, food processing techniques along with change in food habits of people. The pathogen whose reservoirs include the gastrointestinal tract of animals especially ruminants viz., cattle, sheep and goats is mainly transmitted to humans through oral route. The oral route of transmission is of significance as various food products viz., meat, milk and their products derived from animals can be contaminated by intestinal contents of animals during production and ingestion of inappropriate processed foods and could lead to serious complications including haemorrhagic colitis (HC) or the haemolytic uraemic syndrome (HUS) in children [1,2].

In general, the pathogenicity of STEC is governed by two phage - encoded cytotoxins called shiga toxins viz., Stx 1 and Stx2,produced by $s t x 1$ and $s t x 2$ genes, respectively [3]. In addition to these toxins, the presence of eaeA gene encoding 'intimin' protein enhances the virulence of STEC causing intimate attachment to the intestinal epithelial cells [4]. Also, EHEC-hlyA gene encoding enterohaemolysin has synergistic effect on virulence [5].
Thus the aim of this study was to elucidate the presence of E.coli with emphasis on STEC and their virulence determinants in food of animal origin of Jammu region.

\section{Materials and Methods}

A total of 200 samples from foods of animal origin viz.mutton, chicken meat, milk, and milk products (ice-cream, kulfi, paneer, milk cake, rasmalai, cream roll) were collected (Table-1) from Jammu region and processed as per the standard microbiological techniques [6]. The isolation of E.coli was achieved by enrichment in selective E. coli broth and plating on MacConkey agar (MA). 3-4 lactose fermenting colonies from MA were selected and streaked on EMB agar. The colonies producing metallic sheen were selected for biochemical identification.

Serogrouping: All the E. coli isolates were serotyped from National Salmonella and Escherichia Centre, Central Research Institute, Kasauli-173204 (H.P) India.

Polymerase Chain Reaction (PCR) for detection of stx1, stx2, eaeA and EHEC-hlyAgenes: Primers used in the study are listed in Table 2. The template DNA was prepared as per the method of Blanco et al. [8] with slight modifications. The E. coli isolates were cultured 
Table-1. Distribution of samples collected

\begin{tabular}{lcc}
\hline Sr.No. & Types of sample & No. of samples \\
\hline 1. & Mutton & 50 \\
2. & Chicken & 50 \\
3. & Milk & 53 \\
4. & Milk products & 47 \\
Total & & $\mathbf{2 0 0}$ \\
\hline
\end{tabular}

Table-2. List of oligonucleotide primers*(5-3) used for detection of stx1, stx2, eaeA, and EHEC-hlyA gene

\begin{tabular}{llcc}
\hline Primer & Sequence $\left(5^{\prime}-\mathbf{3}^{\prime}\right)^{*}$ & Amplicon size & Reference \\
\hline Stx1-F & CAACACTGGATGATCTCAG & $350 \mathrm{bp}$ & {$[7]$} \\
Stx1-R & CCCCCTCAACTGCTAATA & & \\
Stx2-F & CTTCGGTATCCTATTCCGG & $478 \mathrm{bp}$ & {$[8]$} \\
Stx2-R & GGATGCATCTCTGGTCATTG & \multirow{2}{*}{$384 \mathrm{bp}$} & {$[3]$} \\
EaeA-F & GACCCGGCACAAGCATAAGC & $534 \mathrm{bp}$ & {$[3]$} \\
EaeA-R & CCACCTGCAGCAACAAGAGG & & \\
HlyA-F & GCATCATCAAGCGTACGTTCC & & \\
HlyA-R & AATGAGCCAAGCTGGTTAAGCT & &
\end{tabular}

Table-3. Prevalence of $E$. coli in foods of animal origin

\begin{tabular}{llccc}
\hline S.No. & Types of samples & Samples analyzed & Positive for E. coli & Prevalence ofE. coli (\%) \\
\hline 1. & Mutton & 50 & 15 & 30.0 \\
2. & Chicken & 50 & 20 & 40.0 \\
3. & Milk & 53 & 18 & 33.96 \\
4. & Milk products & 47 & 07 & 14.89 \\
& Total & $\mathbf{2 0 0}$ & $\mathbf{6 0}$ & $\mathbf{3 0 . 0}$ \\
\hline
\end{tabular}

in brain heart infusion broth at $37^{\circ} \mathrm{C}$ for 4 hours. One $\mathrm{ml}$ of the broth culture was centrifuged at $8000 \mathrm{rpm}$ for 5 minutes followed by washing of pellet with NSS at $8000 \mathrm{rpm}$ for 5 minutes. The pellet was mixed with 0.5 $\mathrm{ml}$ of nuclease free water and subjected to heat lysis in boiling water bath for 10 minutes followed by immediate cooling at $-20^{\circ} \mathrm{C}$ for 10 minutes. The mixture was centrifuged at $400 \mathrm{rpm}$ for 4 minutes. $2.5 \mu \mathrm{l}$ of supernatant was used as template for PCR.

For stx genes duplex PCR as per the method of Paton and Paton, [3] with suitable modifications was employed using following reaction mixture components:

10X Taq buffer (with $1.5 \mathrm{mM} \mathrm{MgCl}_{2}$ ) $=2.5 \mu \mathrm{l}$, Deoxynucleotide triphosphate $(\mathrm{dNTP}) 200 \mu \mathrm{M}$ each $=2.5 \mu \mathrm{l}, \mathrm{MgCl}_{2}(25 \mathrm{mM})=2.5 \mu \mathrm{l}$, Primers $10 \mathrm{pmol}$ each $=1.0 \mu \mathrm{l}$, Taq DNA polymerase $1 \mathrm{U}=0.5 \mu \mathrm{l}$, Template DNA $=2.5 \mu \mathrm{l}$, Nuclease free water up to $=25 \mu \mathrm{l}$

PCR was performed in eppendorf gradient thermo-cycler with heated lid using cycling conditions as follows: initial denaturation at $94^{\circ} \mathrm{C}$ for 4 minutes, 35 amplification cycles each of 1 minute denaturation at $94^{\circ} \mathrm{C}$, annealing at $55^{\circ} \mathrm{C}$ for 1 minute and extension at $72^{\circ} \mathrm{C}$ for 1 minute followed by a final extension at $72^{\circ} \mathrm{C}$ for 7 minutes. The PCR product was analyzed byagarose gel electrophoresis. The PCR for eaeA and EHEC-hlyA genes was performed as per the method of [3] with minor modifications. For both genes, the cyclic conditions were different while the reaction mixture components were same. The components for reaction mixture were: 10X Taq buffer (with $1.5 \mathrm{mM} \mathrm{MgCl}$ ) $=2.5 \mu \mathrm{l}$, Deoxynucleotide triphosphate (dNTP) $200 \mu \mathrm{M}$ each $=2.5 \mu \mathrm{l}, \mathrm{MgCl}_{2}$ $(25 \mathrm{mM})=2.5 \mu \mathrm{l}$, Primers $10 \mathrm{pmol}$ each $=1.0 \mu \mathrm{l}$, Taq DNA polymerase $1 U=0.5 \mu \mathrm{l}$, Template DNA $=2.5 \mu \mathrm{l}$, Nuclease free water up to $=25 \mu \mathrm{l}$

The cycling parameters used were initial denaturation at $94^{\circ} \mathrm{C}$ for $5 \mathrm{~min}$ followed by 34 cycles of denaturation at $94^{\circ} \mathrm{C}$ for 1 minute, annealing at $62^{\circ} \mathrm{C}$ for 1 minute and extension at $72^{\circ} \mathrm{C}$ for 1 minute followed by final extension at $72^{\circ} \mathrm{C}$ for 1 minute; while for eaeA gene amplification, the thermocycler conditions were same as those of $h l y A$ except that the annealing temperature used for $e a e A$ was $63^{\circ} \mathrm{C}$ for 1 minute.

The amplified products were analysed by electrophoresis in $1.5 \%$ agarose gel containing ethidium

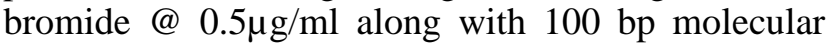
weight DNA marker (Bangalore Genei)in horizontal electrophoresis unit (Biometra, Germany) for 2 hours at $7 \mathrm{v} / \mathrm{cm}$. The gel was visualized under UV trans- illuminator (Biometra, Germany).

Antibiotic sensitivity/ Resistance pattern of E.coli isolates: A total of 50 isolates ( 25 from mutton and chicken meat and 25 from milk and milk products) were subjected to disc diffusion antibiotic sensitivity testagainst 15 commonly used antibiotics (Table-6)[9]. The results were interpreted as per supplier's instructions.

\section{Results}

Prevalence of E. coli in foods of animal origin: On testing 200 samples of foods of animal origin, the overall prevalence of $E$. coli was $30 \%$ (60) including $30 \%$ mutton, $40 \%$ chicken, $33.96 \%$ milk and $14.89 \%$ milk products positive for $E$. coli (Table-3).

Serogroups of E. coli isolates: The $60 \mathrm{E}$. coli isolates belonged to 24 different serogroups with 5 rough and 18 untypeable strains. The detailed results of $E$. coli serogroups of each category of food are shown in Table-4.

Detection of stx1,stx2, eaeA and EHEC-hlyA genes: Screening of samples for the presence of stx 1 , stx2, $e a e A$ and $E H E C$-hlyA gene was done by PCR (Fig. 1 \& 2). Sixty $E$. coli isolates comprising of 15 from mutton, 20 from chicken meat, 18 from milk, and 7 from milk products were examined for the presence of these genes. 38(19\%) of samples possessed stxland/or stx2 genes and were designated as STEC. PCR revealed that $21(10.5 \%)$ samples harboured only stxl gene, $14(7 \%)$ only stx 2 and $3(1.5 \%)$ both stxland stx 2 genes; whereas $8(4 \%)$ possessed the eaeA geneonly but not stx designated as Enteropathogenic E. coli (EPEC) (Table5). Only 4(2\%) samples possessed EHEC-hlyA gene belonging to serogroup O60, O101, O131 and one untypeable strain.

Prevalence of (STEC) and enteropathogenic E. coli (EPEC) among mutton, chicken meat, milk and milk product samples: Prevalence of STEC and EPEC from mutton, chicken meat, milk and milk products samples is presented in table 5. $20 \%$ mutton samples yielded STEC belonging to serogroup O60(4), O80, O22(2), O102, with one rough, and one untypeable whereas $2 \%$ belonging to serogroup O123were EPEC. $30 \%$ samples carrying $E$. coli strains belonging to seven sergroups (O5, O8, O20, O22(2), O102, O147, O162, 
Table-4. Distribution of E. coli serogroups in foods of animal origin

\begin{tabular}{|c|c|c|}
\hline Types of Sample Analysed & No. of E. coli isolates & Serogroups" \\
\hline $\begin{array}{l}\text { Mutton } \\
\text { Chicken } \\
\text { Milk }\end{array}$ & $\begin{array}{l}15 \\
20 \\
18\end{array}$ & $\begin{array}{l}\text { O22(2), O60(4), O80(1), O102(1), O123(5), R*(1), UT*(1) } \\
\text { O5(1), O8(1), O20(1), O22(2), O102(1), O147(1), O162(1), R(2), UT (10). } \\
\text { O12(1), O15(1), O23(1), O36(1), O86(1), O95(1), O100(1), O101(1), O109(1), } \\
\text { O117(1), O131(1), O156(1), O164(1), R*(2), UT'(3). }\end{array}$ \\
\hline $\begin{array}{l}\text { Milk products } \\
\text { Total }\end{array}$ & $\begin{array}{l}07 \\
60\end{array}$ & $\mathrm{O} 60$ (1), O82 (1), O144 (1), UT (4). \\
\hline
\end{tabular}

* R=rough, UT= untypeable, "figure in parenthesis indicates number of isolates

Table-5. Genetic profile and prevalence of Shiga toxin-producing E. coli (STEC) and Enteropathogenic E. coli (EPEC) from foods of animal origin*

\begin{tabular}{|c|c|c|c|c|c|c|c|}
\hline $\begin{array}{l}\text { Types of samples } \\
\text { analysed }\end{array}$ & $\begin{array}{l}\text { No. of samples } \\
\text { analysed }\end{array}$ & $\begin{array}{l}\text { Prevalence } \\
\text { stx1 }\end{array}$ & stx2 & stx1\& stx2 & EHEC-hlyA & EPEC (eaeA) & STEC \\
\hline Mutton & 50 & $5(10)$ & $4(8)$ & $1(2)$ & $1(2.0)$ & $1(2.0)$ & $10(20.0)$ \\
\hline Chicken & 50 & $9(18)$ & $5(10)$ & $1(2)$ & $1(2.0)$ & $2(4.0)$ & $15(30.0)$ \\
\hline Milk & 53 & $5(9.43)$ & $3(5.66)$ & $1(1.88)$ & $2(3.77)$ & $4(7.54)$ & $9(16.98)$ \\
\hline M. products & 47 & $2(4.25)$ & $2(4.25)$ & $0(0)$ & - & $1(2.12)$ & $4(8.51)$ \\
\hline Total & 200 & $21(10.5)$ & $14(7)$ & $3(1.5)$ & $4(2.0)$ & $8(4)$ & $38(19.0)$ \\
\hline
\end{tabular}

"figure in parenthesis indicates number of isolates

Table-6. Antimicrobial sensitivity/resistance pattern of E. coli isolates from meat, milk and milk products

\begin{tabular}{|c|c|c|c|c|c|c|c|}
\hline \multirow[t]{2}{*}{ Sr.No. } & \multirow[t]{2}{*}{ Antimicrobial agents } & \multicolumn{3}{|c|}{ No. of isolates from Meat $(n=25)$} & \multicolumn{3}{|c|}{$\begin{array}{l}\text { No. of isolates from Milk \& Milk } \\
\text { products }(n=25)\end{array}$} \\
\hline & & S* & I* & $\mathbf{R}^{*}$ & $\mathbf{S *}$ & |* & $\mathbf{R}^{*}$ \\
\hline 1 & Amikacin (Ak), 30 $\mu \mathrm{g}$ & $19(76)$ & 0 & $6(24)$ & $18(72)$ & $2(8)$ & $5(20)$ \\
\hline 2 & Ampicillin, $(A), 10 \mu \mathrm{g} \quad 8(32)$ & $1(4)$ & $16(64)$ & $9(36)$ & $2(8)$ & $14(56)$ & \\
\hline 3 & 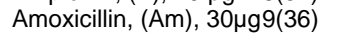 & $2(8)$ & $14(56)$ & $8(32)$ & $3(12)$ & $14(56)$ & \\
\hline 4 & Cephotaxime (Ce), 30 $\mu \mathrm{g}$ & $13(52)$ & $2(8)$ & $10(40)$ & $12(48)$ & $2(8)$ & $11(44)$ \\
\hline 5 & Chloramphenicol(C) $30 \mu \mathrm{g}$ & $20(80)$ & $5(20)$ & 0 & $19(76)$ & $3(12)$ & $3(12)$ \\
\hline 6 & Ciprofloxacin (Cf) $5 \mu \mathrm{g} \quad 15(60)$ & $2(8)$ & $8(32)$ & $15(60)$ & 0 & $10(40)$ & \\
\hline 7 & Co-trimoxazole $(\mathrm{Co}) 25 \mu \mathrm{g}$ & $16(64)$ & $4(16)$ & $5(20)$ & $15(60)$ & $5(20)$ & $5(20)$ \\
\hline 8 & Colistin, (Cl) $10 \mu \mathrm{g}$ & $1(4)$ & $8(32)$ & $15(60)$ & 0 & $10(40)$ & \\
\hline 9 & Cephoxitin (Cn) 30ug $21(84)$ & $2(8)$ & $2(8)$ & $20(80)$ & $2(8)$ & $3(12)$ & \\
\hline 10 & Gentamicin (G), $10 \mu \mathrm{g} 20(80)$ & $2(8)$ & $3(12)$ & $18(72)$ & $2(8)$ & $5(20)$ & \\
\hline 11 & Nalidixic acid (Na) $30 \mu \mathrm{g}$ & $14(56)$ & $3(12)$ & $8(32)$ & $15(60)$ & $2(8)$ & $8(32)$ \\
\hline 12 & Norfloxacin (Nx), $10 \mu \mathrm{g} 21(84)$ & $3(12)$ & $1(4)$ & $20(80)$ & $3(12)$ & $2(8)$ & \\
\hline 13 & Tetracycline, $(\mathrm{T}), 30 \mu \mathrm{g} 20(80)$ & $2(8)$ & $3(12)$ & $19(76)$ & $3(12)$ & $3(12)$ & \\
\hline 14 & Tobramycin (Tb), $10 \mu \mathrm{g}$ & $19(76)$ & $3(12)$ & $3(12)$ & $18(72)$ & 0 & $7(28)$ \\
\hline 15 & Streptomycin (S), $10 \mu \mathrm{g}$ & $19(76)$ & $2(8)$ & $4(16)$ & $18(72)$ & $2(8)$ & $5(20)$ \\
\hline
\end{tabular}

$\mathrm{S}=$ Sensitive, $\mathrm{R}=$ Resistant, $\mathrm{I}=$ Intermediate, $\mathrm{n}=$ number of the isolates tested, figure in parenthesis indicates number of isolates

with two rough, and 5 untypeable from chicken meat were STEC and $4 \%$ were EPEC from chicken meat carrying E. coli isolates, one rough and one untypeable. The prevalence of the STEC and EPEC was $16.98 \%$ and $7.54 \%$ from milk, $4.25 \%$ and $2.12 \%$ that of milk products samples respectively.

Antimicrobial sensitivity/ resistance pattern of E.coli isolates from meat: Out of 35 isolates from meat (mutton and chicken), 25 were tested against various antibiotics for sensitivity/resistance pattern. It was found that 10 of $25(40 \%)$ isolates revealed multidrug resistance to four or more antibiotics. $76 \%$ of isolates were sensitive to Amikacin, Streptomycin and Tobramycin, $80 \%$ to Chloramphenicol, Gentamicin and Tetracycline, $84 \%$ to Norfloxacin and Cephoxitin, $60 \%$ to Ciprofloxacin, $64 \%$ to Colistin and Cotrimoxazole, and $32 \%$ to Ampicillin, $36 \%$ to Amoxycillin, $52 \%$ to Cephotaxime and $56 \%$ to Nalidixic acid. Whereas $24 \%$ isolates showed resistant to Amikacin, $64 \%$ to Ampicillin, and 56\% to Amoxycillin $40 \%$ to Cephotaxime, $32 \%$ to Nalidixic acid, Ciprofloxacin, and Colistin, $20 \%$ to Co-trimoxazole, $12 \%$ to Tetracycline, Tobramycin, Gentamicin and $16 \%$ to Streptomycin. Where, as $20 \%$ intermediate sensitivity was shown against Chloramphenicol (Table 6).

Antimicrobial sensitivity/ resistance pattern of E. coli isolates from milk and milk products: Twelve of $25(48 \%)$ isolates from milk and milk products showed multidrug resistance to four and more antibiotics. But $80 \%$ were sensitive to Norfloxacin and Cephoxitin. $76 \%$ to Tetracycline and Chloramphenicol, $72 \%$ to Amikacin, Gentamicin, Tobramycin, and Streptomycin, $60 \%$ to Ciprofloxacin, Co-trimoxazole, Colistin, and Nalidixic acid, where as $56 \%$ of isolates were resistant to Amoxycillin, and Ampicillin, 44\% to Cephotaxime, $40 \%$ to Ciprofloxacin and colistin, $20 \%$ to Amikacin, Co-trimoxazole, Gentamicin, and Streptomycin, $28 \%$ to Tobramycin, $12 \%$ Tetracycline. $32 \%$ to Nalidixic acid (Table 6).

\section{Discussion}

Due to ability of STEC to cause outbreaks of fatal illness it has attracted worldwide attention and many studies on STEC have been conducted in different parts of the globe.

It was observed that 60 of $200(30 \%)$ samples were contaminated with $E$. coli out of which $19 \%$ were possessing STEC. However, the prevalence of STEC was $13 \%$ in milk and milk product samples and $25 \%$ in meat (mutton and chicken) samples. Vernozy-Rozand, et.al. [10] reported 13\% STEC in raw milk products samples and Kiranmayi and Krishnaiah [11] detected $24 \%$ of STEC in mutton and chicken meat samples 

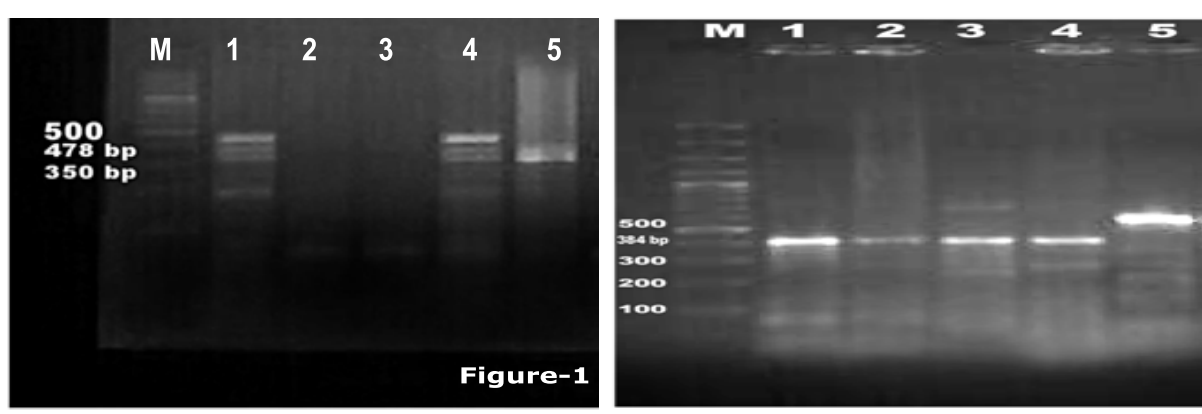

Fig.-1. Agarose gel showing the amplification product of PCR performed on E. coli strains for stxland stx2genes. Lane M: 100 bp molecular weight marker. Lane 1: Positive control of 350 bp of stx 1 and 478 bp of stx2gene, Lane 2 : Negative control, Lane 3: Negative sampla 4. Amplified product of 350 bp of stx 1 and Lane 4: Amplified product of 350 bp of stx1 and478 bp of stx2gene, Lane 5. Amplified product of 350 bp of stx 1 gene

Fig.-2. Agarose gel showing the amplification product of PCR Performed on E. coli strains for eaeA and EHEC-hly genes, Lane M: 100 bp molecular weight marker, Lane 1, 2, 3, 4: Amplified product of $384 \mathrm{bp}$ of eaeA gene, Lane 5 : Amplified product of 534 bp of EHEC-hlyA gene which is in agreement to this study.

The 50 isolates from mutton, chicken meat, milk and milk products were tested against 15 commonly used antimicrobial for the treatment of food animals in different ailments. It was observed that 22(44\%) of isolates were showing multidrug resistance against to four or more antimicrobials which is in agreement to the study of Altalhi, et al. [12], where the multidrug resistance was $40.54 \%$ among the isolates of E. col from chicken meat. However, $84 \%$ of isolates were sensitive to Cephoxitin, $80 \%$ to Chloramphenicol and Tetracycline from the chicken and mutton meat samples whereas, $76 \%$ to Chloramphenicol, from milk and milk product samples.

Antimicrobial resistance in Enterobacteriaceae poses a critical public health threat, especially in the developing countries [13,14]. Much of the problem has been shown to be due to the presence ofTransferable plasmids encoding multidrug resistance and their dissemination among differententerobacterial species [15].

\section{Conclusion}

The direct consumption of raw milk meat and their products or raw meat and partially cooked or prepared under unhygienic conditions remain high risk as they may be carrying STEC. More research in this behalf is needed to know the presence of STEC in raw milk, meat and their products to conclude survival rate and heat tolerance during processing and also to know the possibility of post preparation contamination of products.

\section{Author's contribution}

MR collected and processed the samples, drafted the manuscript. SKK and MAM revised the manuscript MS helped in design, online submission and necessary suggestions. All author read and approved the final manuscript.

\section{Acknowledgements}

The authors are thankful to Ashok Kumar, Head Division of VPH, D. K. Singh, K. Bilgoankar and R. K. Agarwal principal scientists, Division of VPH, IVRI Izatnagar, Bareilly for providing necessary help to carry out this study. We are also thankful to Director, National Salmonella and Escherichia Centre, Central Research Institute Kasauli (H.P) for Serogrouping of E. coli isolates.

\section{Competing interests}

Authors declare that they have no competing interest.

\section{References}

1. Frank, C., Werber, D., Cramer, JP., Askar, M., Faber, M., Heiden, M., et al. (2011) Epidemic Profile of ShigaToxin-ProducingEscherichia coli O104:H4. Outbreak in Germany. NEngl J Med. 365(19):1771-80.

2. Jourdan-da Silva, N., Watrin, M., Weill, F.X., et al. (2012) Outbreak of Haemolytic Uraemic Syndrome due to Shiga Toxin-Producing Escherichia Coli O104:H4 among French Tourists Returning From Turkey, September 2011, Euro Surveillance, 17(4):pii=20065.

3. Paton, A. W., and J. C. Paton. (1998) Detection and characterization of Shiga toxigenic Escherichia coli by using multiplex PCR assays for $s t x_{1}$, stx $x_{2}$ eaeA, enterohemorrhagic E. coli hlyA, $r f b_{0111}$, and $r f b_{0157} . J$. Clin. Microbio.,36:598-602.

4. Jerse, A.E., J.Yu, Tall, B.D. andKaper, J.B. (1990) A genetic locus of enteropathogenicEscherichia coli necessary for the production of attaching and effacing lesions on tissue culture cells. Proc. Natl. Acad. Sci. USA 87: 7839-7843.1.

5. Schmidt, H., Beutin,L. and Karch, H. (1995) Molecular analysis of the plasmid encoded haemolysin of E. coli O157:H7 strain EDL933. Infection Immunology. 63: 1055-1061.

6. Quinn, P.J., Carter, M.E., Markey, B.K. and Carter, G.R. (1994) Clinical Veterinary Microbiology, pp. 21-26 and 209236. ISBN 0723417113.

7. Ramamurthy, T., Nandy, R.K., and Nair, G.B. (2002) Manual of JICA/NICED training course on molecular epidemiology of diarrhoeal diseases with special reference to cholera. NICED, Calcutta, August 12-21.

8. Blanco, M., Blanco, J.E., Blanco, J., Gonzalez, E.A., Mora, A., Prado, C., Fernandez, L., Rio, M., Ramos, J. and Alonso, M.P. (1996) Prevalence and characteristics of E. coli serotype O157:H7 and other verotoxin producing E. coli in healthy cattle. Epidemiology of Infection, 117:251-257.

9. Bauer, A. W., Kirby, W. M. M., Sherris, J. C. and Turck, M. (1966) Antibiotic susceptibility testing by a standardized single disc method. Am J. Clin. Pathol.45(4): 493-496.

10. Vernozy-Rozand, C., Montet, M.P., Beradin, M., Bavai, C. and Beutin, L. (2005). Isolation and characterization of shiga toxin-producing Escherichia coli strains from raw milk cheese in France. Letters in Applied Microbiology, 41: 235-241.

11. Kiranmayi, Ch. Bindu and Krishnaiah, N. (2010). Detection of Escherichia coli $\mathrm{O} 157: \mathrm{H} 7$ prevalence in foods of animal origin by cultural methods and PCR technique. Veterinary World, 3(1):13-16.

12. Altalhi, A.D., Gherbawy, YA., Hassan, SA. (2010) Antibiotic resistance in Escherichia coli isolated from retail raw chicken meat in Taif, Saudi Arabia. Foodborne Pathogens and Diseases 7(3):281-5.

13. World Health Organization (WHO). (1997). The world health report 1996-Fighting disease, fostering development. World Health Forum, 18: 1-8.

14. Karlowsky, J.A., Jones, M.E., Thornsberry, C.,Friedland, I.R. (2003). Trends in antimicrobialsusceptibilities among Enterobacteriacaeisolated from hospitalized patients in the United Statesfrom 1998-2001. Antimicrobial Agents and Chemotherapy, 47: 1672-1680.

15. Carattoli, A. (2009) Resistance plasmid families in Enterobacteriaceae. Antimicrobial Agents and Chemotherapy,53: 2227-2238.

$* * * * * * * *$ 